\title{
IQTISHODUNA
}

IQTISHODUNA: Jurnal Ekonomi Islam

E-ISSN: 2443-0056, P-ISSN: 2252-5661

Accredited Sinta 2 Number 148/M/KPT/2020

Volume 10 Issue 1, April 2021 | Page: 059-076

DOI: $\underline{\text { doi.org/10.36835/iqtishoduna.v10i1.955 }}$

\section{Towards Rahmatan lil 'Alamin Economy (Analysis of Ukhuwah Islamiyah and Ashabiah for Economic Development in Medina)}

\author{
Moh. Syarifudin', Nur Kholis ${ }^{2 *}$ \\ ${ }^{1}$ Departement of Islamic Economics, Faculty of Islamic Economics and Business, Fakultas \\ Ekonomi dan Bisnis Islam, Institut Agama Islam Negeri Fattahul Muluk Papua, Jln. Merah \\ Putih Buper Yabansai Heram Kota Jayapura Papua 99224, Indonesia \\ ${ }^{2}$ Departement of Islamic Economics, Faculty of Islamic Economics and Business, Universitas \\ Islam Negeri Sunan Ampel Surabaya, Jl. Ahmad Yani No. 117 Surabaya 60237, Indonesia
}

\begin{abstract}
Islam provides fundamental sources for human development, including ukhuwah Islamiyah, ashabiah and rahmatan lil 'alamin. These concepts are strategic in developing the economy of the state. The current article aims to analyze the economic development in Medina carried out by the Prophet Muhammad. The authors employed a qualitative method through narrative reviews of the extant literature. The study shows that before the hijrah of the Prophet, Medina was already a multicultural and heterogeneous society with many prolonged conflicts.. The Prophet devised a strategic approach to build the Medina economy and society. Ukhuwah Islamiyah was used to unify differing, often conflicting cultures, beliefs, and ethnicities to form a strong brotherhood. Ashabiah was applied to tighten the glue among society members, creating high social solidarity. Upon the perfection of Medina, the apostolate of rahmatan lil 'alamin leads to a universal, inclusive, and sustainable economic development.
\end{abstract}

Keywords: Ashabiah, economic development, Medina, rahmatan lil 'alamin, ukhuwah Islamiyah

Article History:

Received: January 7, 2021; Accepted: January 25, 2021; Published:

April 1, 2021

*Corresponding author: e-mail nurkholis@uinsby.ac.id

Paper type: Conseptual paper

Cite this document: Syarifudin, Moh., AND Kholis, Nur. " Towards Rahmatan lil 'Alamin Economy (Analysis of Ukhuwah Islamiyah and Ashabiah for Economic Development in Medina)" IQTISHODUNA: Jurnal Ekonomi Islam [Online], Volume 10 Number 1 (April 1, 2021)

Abstrak: Islam menyediakan sumber fundamental bagi pembangunan manusia, misalnya ukhuwah Islamiyah, ashabiah dan rahmatan lil 'alamin. Konsep-konsep ini sangat strategis dalam membangun perekonomian negara. Artikel ini bertujuan untuk menganalisis pembangunan ekonomi di Madinah yang dilakukan oleh Nabi Muhammad. Metode kualitatif digunakan melalui tinjauan naratif dari literatur yang tersedia. Studi ini menunjukkan bahwa sebelum hijrah Nabi, Madinah telah menjadi masyarakat multikultural dan heterogen dengan banyak konflik yang berkepanjangan. Nabi merancang pendekatan strategis untuk membangun ekonomi dan masyarakat Madinah. Ukhuwah Islamiyah digunakan untuk menyatukan budaya, kepercayaan, dan etnis yang berbeda untuk membentuk persaudaraan yang kuat. Ashabiah diaplikasikan untuk mempererat ikatan antar anggota masyarakat, sehingga tercipta solidaritas sosial yang tinggi. Dengan kesempurnaan Kota Madinah, kerasulan rahmatan lil 'alamin menjadi strategi pembangunan ekonomi yang universal, inklusif, dan berkelanjutan.

Kata kunci : ashabiah, madinah, pembanguan ekonomi, rahmatan lil 'alamin, ukhuwah islamiah 


\section{INTRODUCTION}

Medina was known as Yathrib before the advent of Islam. ${ }^{1}$ As a part of the Middle Eastern nation experiencing setbacks and deterioration in the appreciation of divine and humanitarian deeds, it was a conflict-ridden city and has not been systematically and adequately organized, both in politics, society, and culture. The society is heterogeneous in terms of ethnicity, leading to a prolonged conflict between the two main tribes in Medina: the Aus and the Kharaj. ${ }^{2}$

Differences in beliefs and faiths of the native Medina and the Jewish immigrants were also contributors to the conflict in Medina. The absence of a social, cultural, political, and especially economic order has brought the people of Medina to be like a forest with all its problems. The stronger and winner in a war will become the ruler with all its consequences.

The prolonged conflict, natural conditions, and weak Economy in Medina have brought its citizens trapped in poverty and underdevelopment. The condition of society like this is a challenge for the Prophet Muhammad's arrival in this city. It was not easy for Allah's Messenger to preach and develop

${ }^{1}$ A. Sulaiman Abdo and John Bagot Glubb, "Medina," Encyclopedia Britannica, accessed March 19, 2021, https://www.britannica.com/place/Medin a-Saudi-Arabia.

2Yusno Abdullah Otta, "Madinah Dan Pluralisme Sosial (Studi Atas Kepemimpinan Rasulullah)," Jurnal AlSyir'ah 8, no. 2 (2010): 486. the Medina society with various conflicts, heterogeneity, and illmanaged social, economic, and political conditions. A unique strategy was needed to make his apostolic mission successful and bring significant changes to Medina.

The concept of ukhuwah Islamiyah (brotherhood in the shade of the flag of Islam) based on the Qur'an and the Sunnah is a strategic concept to face challenges in Medina. Uniting various thought patterns and activities of community life based on brotherhood is one of the keys to dakwah strategy and the development of Medina. ${ }^{3}$ Problemsolving from the roots and social potentials with equality is a concept conveyed by the figure of Islamic sociologist Ibn Khaldun. He proposed that ashabiah (potential fanaticism/community loyalty to a particular group of descendant, clan, ethnicity, and religion) is an essential factor in mobilizing community solidarity in social, political, and economic fields. ${ }^{4}$

The concept of ukhuwah Islamiyah binds and unites human thought patterns and activities within Islamic brotherhood, which is binding and universal. It is the door to a strategy for settlement and management of the plural and multicultural of Medina society. In

${ }^{3}$ Ali Anas Nasution, "Persaudaraan dalam Perspektif al-Qur'an," HIKMAH: Jurnal Ilmu Dakwah dan Komunikasi Islam 7, no. 2 (July 2013): 142.

${ }^{4}$ Hakimul Ikhwan Affandi, Akar Konflik Sepanjang Zaman: Elaborasi Pemikiran Ibn Khaldun, Cet. 1. (Yogyakarta: Pustaka Pelajar, 2004), 105.

60| Copyright (C 2021, IQTISHODUNA: Jurnal Ekonomi Islam

http://ejournal.iaisyarifuddin.ac.id/index.php/iqtishoduna 
principle, ukhuwah Islamiyah is often interpreted as synonymous with the concept of ashabiah, which makes religion the main factor in generating synergy in community development with the solidarity of the Muslim community. However, the debate arose when it came to making religion a source of loyalty and solidarity. In the study of tafsir and hadith, many argue that ukhuwah Islamiyah should focus on fellow Muslims. Besides, the concept of ashabiah seems to divert fanatic solidarity and loyalty from a clan, ethnicity, and the descendant to religion (Islam).

This study aims to discuss the concept of ukhuwah Islamiyah, ashabiah, and rahmatan lil 'alamin in economic development as performed by the Prophet Muhammad in Medina. The article contributes to the formulation of the Islamic economic development strategies applied to improve the Muslim economy and humankind.

\section{Past Medina at Glance}

Rasulullah's journey in Makkah for 13 years, both secretly and openly, 5 has not obtained optimal results; even the opposition and threats of murder befell Rasulullah and his companions who had converted to Islam. ${ }^{6}$ The opposition and the conspiracy of the infidel

${ }^{5}$ Badri Yatim, Sejarah Peradaban Islam (Jakarta: Rajawali Press, 2016), 20.

${ }^{6}$ Faisal Ismail and Jabir Ahmad alHajjawi, Sejarah dan Kebudayaan Islam Periode Klasik (Abad VII-XIII M) (Yogyakarta: Ircisod, 2017), 155.
Meccan leaders to commit murder drove the Prophet to migrate to Medina. The determination of Rasulullah's migration to Madinah was because there were already some people who have performed bai'at aqobah who are unknown to other nations. ${ }^{7}$ Their arrival was three waves; the first wave in the 10th prophetic year with some professing conversion to Islam, the second wave in the twelfth prophetic year with 12 men and one woman, and the third wave in the thirteenth prophetic year with 73 people and committed to supporting, maintaining and ready to sacrifice his soul, body, and property for the Prophet and Islam. In the next period, when the pressure on the Muslims in Mecca was more extensive, the Prophet ordered 150 Muslims to migrate to Medina in two months. The companions of Ali ibn Abi Talib and Abu Bakr As-Sidik remained in Makkah until they migrated with Rasulullah to Madinah. ${ }^{8}$

There are several factors about the acceptance of Islam in Medina; the first is that there was already a heavenly religion in Medina, namely Judaism, which has discussed a lot about the arrival of the last Prophet. Second, the threat of the Jews against the Arabs of Yathrib; if they see Muhammad arrives, they will expel

7Ibid., 156.

${ }^{8}$ Abdurrahman Muhammad Ibn Khaldun, Tārikh al-'Allāmah Ibn Khaldūn: kitāb al-'abr wa-dìwān al-mubtadā wa-al-khabar fi ayyām al-'Arab wa-al-'ajam wa-Barbar waman 'āsarahum min dhawi al-sulțān al-akbar, vol. 2 (Beirut: Dar al Fikr, 1981), 421-422. 
him. Third, the long-standing rivalries of the Aus and Kharaj tribes deliberately sought partners to strengthen their group. ${ }^{9}$ The first step of Rasulullah to build Madinah was to establish the Prophet's mosque $^{10}$ as a center of worship, information, the council of science and politics. The mosque is a center of civilizational, cultural, social, and political changes, ${ }^{11}$ which later produced many great and qualified scholars, politicians, and leaders in their field.

The Medina people's sociopolitical aspects were very diverse and pluralistic because never before had been a ruler who can unite them in one leadership. This situation was different from that in Mecca, where the holders of political and economic power were in the hands of the Quraish aristocracy, which is the most dominant tribe. The protracted conflict between the Aus and Khazraj tribes in Medina made them never united, even though they were of one faith and trust. The victory of the 'Aus tribe over the Khazraj in the $B u^{\prime}$ ats battle shows the weakness of the Medina people in forging unity due to leadership crisis. ${ }^{12}$ The population of post-migration Medina

\footnotetext{
${ }^{9}$ Ahmad Al-Usairy, Sejarah Islam: Sejak Zaman Nabi Adam Hingga Abad XX (Jakarta: Akbar Media Eka Sarana, 2013), 99.

${ }^{10}$ Dedi Supriyadi, Sejarah Peradaban Islam (Bandung: Pustaka Setia, 2016), 63.

${ }^{11}$ Hamid Fahmy Zarkasyi, Peradaban Islam: Makna Dan Strategi Pembangunannya (Ponorogo: CIOS, 2010), 18.

12Otta, "Madinah Dan Pluralisme Sosial (Studi Atas Kepemimpinan Rasulullah)," 486.
}

was even more pluralistic than premigration. They consisted of the Medina Arabs who have converted to Islam called the Anshar, the people of Mecca who migrated called the Muhajirin, a group of people of Medina who still adhere to paganism, the Jews consisting of various tribes, both Arabs and Jews themselves, the hypocrites and polytheists of Madinah, and the Christian minorities. ${ }^{13}$ The Jews held almost all sectors of the economy, especially agriculture and industry, and dominated the market. They were the immigrants who owned the land and controlled the capital, while the Arabs only became the secondclass economic servants in their state. Finally, they had tribal prejudices on different customs. ${ }^{14}$ This situation forces each group to act alone to realize their interests in achieving progress according to the principles and philosophy of life they believe in and their culture.

\section{Ukhuwah Islamiyah as the Socio- Economic Foundation}

The Islamic teachings give the concept of brotherhood (ukhuwah). In the Qur'an, there are verses with 74 words peaking about brotherhood. The word ukhuwah comes from the Arabic word $\dot{\tau}^{\prime}$ which means brother and friend. God's creatures are also

13J. Suyuthi Pulungan, Prinsip-Prinsip Pemerintahan Dalam Piagam Madinah Ditinjau Dari Pandangan Al-Qur'an (Jakarta: RajaGrafindo Persada, 1994), 57.

${ }^{14}$ Otta, "Madinah Dan Pluralisme Sosial (Studi Atas Kepemimpinan Rasulullah)," 487.

62| Copyright (C 2021, IQTISHODUNA: Jurnal Ekonomi Islam http://ejournal.iaisyarifuddin.ac.id/index.php/iqtishoduna 
brothers because they are both God's creation and subject to God. Then all human beings are brothers because they come from one ancestor. The community is a brotherhood, and fellow Muslims are brothers. The spirit of equality among fellow Muslims should be based on Allah alone because it is a barometer to measure excellent and destructive relationships. ${ }^{15}$

Surah al-Hujurat - 49:10 uses the word ikhwah translated as brothers. ${ }^{16}$ The words ikhwah and ikhwan are the plurals of the word akh [un] (brother). The words ikhwah and ikhwan can be used interchangbly. However, generally, the word ikhwah indicates relatives, while ikhwan indicates friends and companions. ${ }^{17}$ Although the word innama does not always mean hasyr (restriction), there is no brotherhood except fellow believers, ${ }^{18}$ indicating that the Islamic brotherhood is stronger than the lineage brotherhood.19 The brotherhood between fellow believers is forged by the similarity of faith and by reconciling two brothers. Because

${ }^{15}$ Ali Anas Nasution, "Persaudaraan dalam Perspektif al-Qur'an," HIKMAH: Jurnal Ilmu Dakwah dan Komunikasi Islam 7, no. 2 (July 2013): 143.

16Quran.com, "Surah Al-Hujurat - 49:10," accessed March 16, 2021, https: / / quran.com/49/10?translations=20.

17Muhammad ibn Abī Bakr Rāzī and 'Abd al-Fatt āh Barkāwī, Mukhtār al-Ṣihāh (Kairo: Dār al-Manār, 1993), 29.

${ }^{18}$ Muhammad Ali al-Sabuni, Safwat AlTafasir, vol. 3 (Beirut: Dar al Fikr, 1996), 235.

${ }^{19} \mathrm{Abu}$ 'Abdullah al-Qurtubi, Tafsir AlQurtubi: Al-Jami' Li-Ahkam al-Qur'an, vol. 8 (Beirut: Risalah Publishing, 2013), 212. they are brothers, their everyday and natural lives are filled with love, peace, and unity. A dispute and war between them is a form of deviation, which must be returned to normal by correcting those in dispute, that is, inviting them to seek a solution to Allah and His Messenger's laws. ${ }^{20}$ The Qur'an usually uses the word ikhwan to indicate a brother who is not a sibling, yet it uses the word ikhwat as a plural form of the word akh to mean siblings. Nevertheless, the brotherhood of fellow Muslims is described with the word ikhwat, "indeed the believers are ikhwat." Thus, the brotherhood of fellow believers is forged by the similarity of faith and hereditary brotherhood. ${ }^{21}$

The step taken by the Prophet to organize and manage the Medina community is by building mutual understanding between the Muhajirin and Anshar with the Islamic brotherhood.22 This step is strategic to eliminate tribal fanaticism that blindly denigrates brotherhood, egalitarianism, pluralism in the banner of Islam. After fellow Muslims were united,

${ }^{20}$ Muhammad Jamaluddin Al-Qasimi, Tafsir al-Qasimi: Mahasin at-Ta'wil, vol. 8 (Dar al-Ihya al-Kutub, 2003), 529.

${ }^{21}$ M. Quraish Shihab Shihab, Tafsir AlMisbah Jilid 2 (Jakarta: Lentera Hati, 2005), 158.

22In practice, the Prophet befriended Abu Bakr with Kharijah bin Zubair, Ja'far bin Abi Talib with $\mathrm{Mu}^{\prime}$ adh ibn Jabal, Umar ibn alKhattab with Itban ibn Malik, dan Abdurrahman ibn Auf with Sa'ad ibn alRabi'. See Imad Abi Fida' Ismail Ibnu Umar Ibnu Katsir, Al-Bida>yah wa al-Niha>yah, Jilid IV, (Hijr: Markaz al-Buhuts wa al-Dirasat alArabiyyah wa al-Islamiyyah, 1997, 554-561 for more examples. 
the Prophet united the people of Medina, divided into the Arab Muslims and Muslims and the Jews with the agreement of the "Medina Constitution." 23 This constitution was later known as the Medina Charter. ${ }^{24}$ It reflects the universal social order containing tribes, clans, ethnicities, religions, and nations. All are to form a container of an agreement to achieve "the divine plan of salvation." 25

The Prophet laid six strong pillars in Medina. First, the religionbased brotherhood of Muhajirin and Anshar replacing the tribe-based brotherhood. The poor Muslim converts were provided with accommodation in the shuffah (bench) of the mosque, later known as ashhab al-shuffah (the People of the Bench), and the self-sufficient Muhajirin and Anshar jointly fulfilled their necessities. ${ }^{26}$ Second, almusawah (equality), with which the Prophet emphatically taught that all human beings are the descendants of Adam whom God created from soil. The Arabs are no more noble than the non-Arabs and vice versa, except because of their piety. Based on this principle, every citizen has the right

\footnotetext{
${ }^{23}$ Muhammad Zafrulla Khan, Muhammad, Seal of The Prophets (Majlis Khuddamul Ahmadiyya UK, 2012), 88.

${ }^{24}$ See Ismail and al-Hajjawi, Sejarah dan Kebudayaan Islam Periode Klasik (Abad VII-XIII M), 163 for more detail about this term.

${ }^{25}$ William Montgomery Watt, Islamic Political Thought (Edinburgh: Edinburgh University Press, 2014), 10.

${ }^{26}$ Dudung Abdurrahman et al., Sejarah Peradaban Islam Dari Masa Klasik Hingga Modern (Yogyakarta: LESFI, 2004), 32.
}

to independence and freedom. Third, al-tasamuh (tolerance) teaches openmindedness to fellow believers enshrined in the Medina Charter. Fourth, al-tashawur (mutual consultation) is the teaching of consultation in some worldly matters. The fifth is al-ta'awun (cooperation), the teaching to help each other in goodness. The last is aladalah (justice) in carrying out the obligations and accepting the rights of each. ${ }^{27}$

Medina society's pluralistic nature demands laws to regulate social order free from obstacles and barriers considered endangering people's lives. ${ }^{28}$ One of the characteristics of civil society realized in Medina is the balance between rights and social obligations. Zakat, infaq, shadaqah, and hibah for Muslims, and jizyah and kharaj for non -Muslims are laws that strengthen balanced rights and social obligation. ${ }^{29}$ The balance of rights and obligations applies to all aspects of social life so that no one group is more respected than the other based on the majority.

The Prophet application of Islamic teachings significantly influences the equality of social status, togetherness, justice, and

\footnotetext{
27Ibid., 33.

${ }^{28}$ Muhammad Yakub, "Islam Dan Solidaritas Sosial: Perkembangan Masyarakat Islam Periode Madinah," Jurnal Pemberdayaan Masyarakat 7, no. 1 (August 24, 2019): 49.

${ }^{29}$ Nur Kholis and Mugiyati, "Distribution of Productive Zakat for Reducing Urban Poverty in Indonesia," International Journal of Innovation, Creativity and Change 15, no. 3 (2021): 1 .
}

64| Copyright (C 2021, IQTISHODUNA: Jurnal Ekonomi Islam http://ejournal.iaisyarifuddin.ac.id/index.php/iqtishoduna 
civilization has made him a pioneer in building a conducive, safe and prosperous Madinah society by utilizing social capital, leading him to be crowned as the most influential figure in the world until now. ${ }^{30}$ Bellah stated that it was not America that started democratic government, but rather the Prophet Muhammad did so 14 centuries ago. ${ }^{31}$ This social contract agreement is the constitutional document for the birth of a sovereign state. In Medina, the Prophet carried out religious duties as the Messenger of Allah and as the head of state ${ }^{32}$ to improve Medina's prosperity using a strategic approach of Islamic brotherhood.

\section{Ashabiah in Forming Islamic Economy}

For improving Medina's Economy, the Prophet first initiated to fulfill the needs of the Muhajirin as they left their merchandise and assets in Mecca when migrating to Medina. Muhammad asked for the help and kindness of the Anshar to help their brothers from Mecca. His call was answered spontaneously by

\footnotetext{
${ }^{30}$ Michael H. Hart, The 100: A Ranking Of The Most Influential Persons In History, 1st edition. (Hudson, N.J.: Kensington, 2015), 13.

${ }^{31}$ Robert N. Bellah, Beyond Belief: Essays on Religion in a Post-Traditional World (Berkeley: University of California Press, 1991), 210.

32S. Moussalli Ahmad, Gordon D Newby, and Ahmad Moussalli, "Muhammad," in The Oxford Encyclopedia of the Islamic World. Oxford Islamic Studies Online, n.d., accessed March 16, 2021, http://www.oxfordislamicstudies.com/opr /t236/e0550.
}

the Anshar, some of whom offered the Muhajirin to cultivate the land for plantations. ${ }^{33}$ The concept of brotherhood produces a mutual bond among humans with the principle of altruism, regardless of ethnicity, religion, politics, and other motives. However, Ibn Khaldun has a different view, that it is challenging to establish brotherhood without ashabiah. Etymologically ashabiah comes from the word ashaba, which means binding. Functionally Ashabiah refers to socio-cultural ties used to measure the strength of a social group. ${ }^{34}$ Besides, ashabiah can also be understood as social solidarity, emphasizing group awareness, cohesion, and unity.

Furthermore, according to Naqvi, the spirit of brotherhood in the Islamic economic system is manifested in three ways: first, the Islamic Economy is directed towards realizing al' adl wal ihsan (justice and virtue). In this context, ethics must dominate economic activity. Second, efforts should be made to have policies that are pro-poor as an attitude of egalitarianism. Third, the state is a regulator and plays an active and positive role in the economy that defends the interests of the public at large, both in consumption and production.

The pillar of brotherhood in Islamic economics is an economic agent not from the religious

\footnotetext{
${ }^{33}$ Ahmad Ibrahim Syarif, Daulat Al-Rasul Fî al-Maî̀nah (Kuwait: Dar al-Bayan, 1972), 86.

${ }^{34}$ Muhammad Mahmud Rabie', The Political Theory of Ibnu Khaldun (Leiden: E. J. Brill, 1967), 165.
} 
affiliation point but the Islamic economic paradigm. Anyone, a Muslim or a non-Muslim, willing to accept Islamic economic norms is seen as an economic agent. Kahf ${ }^{35}$ stipulates several Islamic economic norms: a) God truly owns the world, while humans are khalifah who obey all of His orders, and this has implications for the idea of ownership; 2) since God is Almighty, there is only one rule to be followed, and this norm has implications for an agent in managing the economic system; c) the presence of the afterlife court should encourage agents to seek rewards in both the world and the afterlife. Therefore, even though worldly profit maximization is acceptable, it must still be subjected to the ukhrawî element. Also, Kahf ${ }^{36}$ has placed the role of the state as one of the vital agents of the economy.

In life, there will always be conflicts of personal and social interests. The state is expected to guarantee the creation of a balanced standard of living for all people. Sadr argues that this effort can be realized by promoting brotherhood through education among community members and public policies such as investments directed at assisting the poor through

\footnotetext{
${ }^{35}$ Monzer Kahf, "Islamic Economics: Notes on Definition and Methodology," in International Workshop on the Methodology of Islamic Economics (Nigeria: Bayero University Kano, 1987), 76-82.

${ }^{36}$ Monzer Kahf, The Islamic Economy: Analytical Study of the Functioning of the Islamic Economic System (Canada: Plainfield, 1978), 87.
}

economic regulations that ensure honesty and freedom from exploitation. ${ }^{37}$ Besides, Zarqa' suggests that the Muslim's rational behavior in applying the concept of needs will encourage individuals to reach a level of adequacy. .8

For Ibn Khaldun, religion has an essential role in forming a unity, ashabiah. Unity formed by religion is much stronger than that formed by other factors, such as ethnicity, nationality, descendant, or even family. ${ }^{39}$ Ashabiah can mean the closeness of one's relationship in the group and tries his best to uphold the principles and values of the group. ${ }^{40}$ Various translations exist about the ashabiah, such as group solidarity, sense of group, harmonization, and social cohesion. Ibn Khaldun's thoughts regarding the socio-political conditions of Medina society at that time were three perspectives. First, the psychological perspective is the basis for sentiments and ideas to build social relationships between various people (family, ethnicity, and others). Second, political phenomena

${ }^{37}$ Muhammad Baqr al-Sadr, Iqtishaduna (Tehran: World Organization for Islamic Services, 1981), 76-77.

${ }^{38}$ Anas Zarqa', "Islamic Economics: An Approach to Human Welfare," in Readings in the Concept and Methodology of Islamic Economics, ed. Aidit Ghazali and Syed Omar (Petaling Jaya: Pelanduk Publications, 1989), 43.

${ }^{39}$ A. Rahman Zainuddin, Kekuasaan dan Negara: Pemikiran Politik Ibnu Khaldun (Jakarta: Gramedia Pustaka Utama, 1992), 155.

${ }^{40}$ Affandi, Akar Konflik Sepanjang Zaman, 105.

66| Copyright (C) 2021, IQTISHODUNA: Jurnal Ekonomi Islam http://ejournal.iaisyarifuddin.ac.id/index.php/iqtishoduna 
related to the struggle for power and sovereignty gave birth to empires, dynasties, and the state. ${ }^{41}$ Third, economic phenomena are related to fulfilling economic needs at the individual, family, and country levels. ${ }^{42}$ These three perspectives strongly relate to Ibn Khaldun's concept of ashabiah.

The terms nomadic and permanent are two concepts that often appear in Ibn Khaldun's explanations of society. The nomadic is synonymous with backwardness, primitive and permanent is synonymous with city, civilized, advanced. Ibn Khaldun then classified the two conceptual models from the point of view of social control into two types: badawah and hadarah. Badawah is the concept of a society with a strong Ashabiah, which tends to be primitive, rural, and nomadic. Ibn Khaldun developed the term badawah from his observations of the nomadic, primitive, but powerful Bedouin community.

The concept hadarah is a manifestation of a more complex, permanent, urban civilization, weak solidarity but civilized. According to Khaldun, in the badawah community, blood relations are prioritized so that their social control is still relatively high. On the other hand, in a civilized society, social control is

${ }^{41}$ Abdurrahman Muhammad Ibn Khaldun, The Muqaddimah: An Introduction to History, Abridged Edition. (Princeton, NJ: Princeton University Press, 2015), 123. 80. much lower. ${ }^{43}$ Sociologically, the classification of badawah and hadarah is based on Ashabiah that develops in society, assuming that in the badawah community, Ashabiah is still powerful while in the hadarah community Ashabiah tends to weaken. The concepts of badawah and hadarah in modern sociological theory can be found in Emile Durkheim's thinking with the terms mechanical solidarity (similar to badawah) and organic solidarity (similar to hadarah). ${ }^{44}$

Social solidarity is the essence of social organization, and ashabiah binds groups together through language, culture, and division. When society at different levels: family, clan, tribe, kingdom, and nation, fundamentally tries to approach ideal behavior, it functions normatively and constitutes a unity. ${ }^{45}$ Besides, social solidarity can fundamentally evolve from three relationships: (1) blood relationship; (2) friendly or client relations and equality of fate; and (3) the leader's authority. ${ }^{46}$ Blood ties have binding power on most humans, making them feel the pain that befalls their people. People hate the oppression of their people, and the urge to reject

${ }^{43}$ Fuad Baali et al., Ibn Khaldun dan pola pemikiran Islam (Jakarta: Pustaka Firdaus, 1989), 45.

${ }^{44}$ Khairul Amin, "Badawah \& Hadarah: Konsep Sosiologi Ibn Khaldun," Jurnal Sosiologi Agama 12, no. 1 (December 6, 2018): 85-98.

${ }^{45}$ Akbar S Ahmed, Islam sebagai tertuduh: kambing hitam di tengah kekerasan global (Bandung: Arasy Mizan, 2004), 129.

46Sulasman and Dadan Rusmana, Filsafat Sosial Budaya di Dunia Islam (Bandung: Pustaka Setia, 2013), 186. 
any pain that may befall them is under their nature and embedded in them. If the level of kinship between the two assistants is very close, then it is clear that the bonds of blood, according to the evidence, lead to true solidarity. ${ }^{47}$ There are several factors of social solidarity, including nomadic life in which its social solidarity is fanatical and hearty as it is built based on clan, lineage, and shared interests. 48

Social solidarity is generally not based too much on blood ties but other elements, such as marriage, patronage, shared interests, and leadership (ad-Daulah). ${ }^{49}$ Religion gives meaning to individual and group life and hopes about the permanence of life after death. Religion can be a means for humans to lift themselves from the difficulties of a worldly life full of suffering to spiritual independence. Religion, then, strengthens group norms, moral sanctions for individual actions and forms the basis for common goals and values on which the balance of society lies. ${ }^{50}$

The end goal of social solidarity is sovereignty. People who have social solidarity and become the chief of the tribe and are obeyed will attempt to gain sovereignty as expected. Nevertheless, they will not

\footnotetext{
47Ibn Khaldun, The Muqaddimah, 151.

${ }^{48}$ Mohammad Pribadi, Pemikiran Sosiologi Islam Ibn Khaldun (Yogyakarta: SUKA-Press, 2015), 97.

49Sulasman and Rusmana, Filsafat Sosial Budaya di Dunia Islam, 198.

50Irzum Farihah, "Agama Menurut Ibn Khaldun," Jurnal Fikrah 2, no. 1 (2014): 187205.
}

accomplish this goal perfectly if they do not have the social solidarity leading others to obey them. Thus, the sovereignty of the kingdom is the ultimate goal of social solidarity. Ibn Khaldun has combined psychological and material factors in a dynamic theory of the rise and fall of political power and connected social phenomena as a basic form of human behavior influenced by kinship, reciprocity, and empathic feelings. ${ }^{51}$ The Sharia state has stronger social solidarity because it seizes the harmful consequences, such as tyranny and indulgence. The religious law praises justice, honesty, performance of religious duties and defends them. ${ }^{52}$

The economic concept proposed by Ibn Khaldun, such as tax reduction and government export volume, was a remedy for the economic recession. The government is the largest revenue market. If the government market declines, other markets will also decline. There are several main points on Ibn Khaldun's Economy; the first must start with value, then the division of labor, the price system, the law of supply and demand, consumption and production, money, capital formation, population growth, macroeconomics of taxes and public expenditure, cycles, trade,

\footnotetext{
${ }^{51}$ Francis Fukuyama, Trust: The Social Virtues and The Creation of Prosperity (New York: Free Press, 1996), 99.

52Ibn Khaldun, The Muqaddimah, 37.
}

68| Copyright (C 2021, IQTISHODUNA: Jurnal Ekonomi Islam http://ejournal.iaisyarifuddin.ac.id/index.php/iqtishoduna 
agriculture, industry, and commerce, as well as prosperity rights. 53

Ibn Khaldun explained humans would not be able to live alone, and they will need other people. A man cannot do much without joining other forces if he obtains food for himself and his fellowmen. By working together, humans can meet their needs. ${ }^{54}$ This notion suggests that one community must cooperate and complement each other to meet its needs. Ibn Khaldun's economic theory of Ashabiah is similar to the community-based theory of economy. Economic Ashabiah leads to "community economics," both organic and mechanical.

\section{Development strategy of Economic Rahmatan lil 'Alamin}

Although religion is the most vital community force, the impression of exclusivity is far from the teachings of Islam. Allah revealed Islam through the Prophet Muhammad as an answer to the rise of ethnicity fanatism and unnecessarily social grouping, with the Islamic concept of rahmatan lil 'alamin as stipulated in the Qur'an in Surat al-Anbiyā' verse 107: "We have sent you 'O Prophet' only as a mercy for the whole world."55 The word

\footnotetext{
${ }^{53}$ Irfan Syauqi Beik and Laily Dwi Arsyianti, "Analisa Ekonomi Pertanian Ibn Khaldun," Iqtishodia: Jurnal Ekonomi Islam Republika (September 2010): 5.

54Peter Worsley, The Distribution of Power in Industrial Society (London: Heinemann Educational Books, 1973), 101.

${ }^{55}$ Quran.com, Surah Al-Anbya - 21:107, 2021, accessed March 16, 2021, https:/ / quran.com/21/107.
}

rahmat (mercy) is etymologically identical to the womb, a symbol of a mother's genuine love for her child. This relationship implies that humans have true grace towards others, like a mother who sincerely dedicates herself, time, and energy to looking after and taking care of her child. Mothers need to have a high level of strength and fortitude to control fatigue, anger, and frustration. Humans are encouraged to have a sense of mercy because they are more dependent on compassion than other creatures. ${ }^{56}$ Al-rahmah is the quality of compassion that establishes good deeds towards loved ones. So, the word al-rahmah includes two meanings: compassion and doing good. When it is associated with Allah, mercy means giving favors and virtues, while when it is associated with humans, it means loving and doing favors.

The word rahmatan is a masdar of the word rahima mentioned in the Qur'an four times, while the word rahmatan is repeated 79 times. ${ }^{57}$ According to Shihab, the verse, despite being short, contains four important main points: (1) the messenger of Allah, in this case, is the Prophet Muhammad, (2) the sender, namely Allah, (3) sent to them (al-'alamin), and (4) risalah (treatizes), all of which indicate its characteristics, namely a tremendous

\footnotetext{
${ }^{56}$ Michael Armstrong, A Handbook of Human Resource Management Practice, 7th ed. (London: Kogan Page, 1999), 19.

${ }^{57}$ Muhammad Fuad Abdul Baqi, AlMu'jam al-Muhfahras li Al-Fadl al-Quran (Mesir: Daarul Fikr, 1992), 387-388.
} 
grace as understood from the indefinite form of the word. 58 Rasulullah is a blessing; his arrival brings teachings, and his figure and personality are blessings bestowed on him by Allah. This verse fragment is one proof that Allah educated and shaped the personality of the Prophet Muhammad as he said: "My God educated me, so the results of His education are excellent." His personality is perfectly shaped so that not only can Allah's knowledge bestow upon him through the Qur'an revelations, but also his heart is illuminated, and even his complete form is a blessing for all nature.

In the Islam rahmatan lil 'alamin there is a brotherhood that teaches mutually beneficial brotherhood among humans, including the economy. Islam also emphasizes altruism, the attitude of being not selfish to others. In the Qur'ân, altruism is termed $i^{\prime}$ tsar. Allah says in the Qur'ân surah al-Hashr verse 9: "They love those who emigrated to them and find not any want in their breasts of what they [i.e., the emigrants] were given but give [them] preference over themselves, even though they are in privation." 59 This doctrine implies a sense of brotherhood in economic activity and mutual help and cooperation between people, an egalitarian

${ }^{58}$ M. Quraish Shihab Shihab, Tafsir AlMisbah Jilid 7 (Jakarta: Lentera Hati, 2005), 519.

${ }^{59}$ QuranTranslate.com, "Surah Al-Hashr Ayah 9 - English Translation Quran Translate," QuranTranslate.Com, accessed March 16, 2021, https://www.alquran.cc/59/9. attitude built into economic activity. In the concept of brotherhood, the prioritized attitude is to sacrifice for one another and work together to meet their poor or needy siblings' immediate needs. ${ }^{60}$ The Prophet said: "It is not a believer person if he eats well while his neighbor is starving."61 Brotherhood leads to mutual benefit, resulting in equitable justice, compassion, care, prosperity, and wisdom. In this sense, brotherhood is one aim of shariah. 62

According to Mannan, there is no conflict between individual freedom and social control; even the two are seen as complementary. The relationship between individuals, society, and the state is purposeful and based on goodwill and harmonious cooperation to achieve the goals of the economic system. 63 Based on the Islamic concept, the character building of economic actors is based on the economic form of brotherhood. On a positive note, the payment of zakat has become an essential part of the Islamic faith. The spiritual discipline inculcated from prayer will lose its practical meaning if Muslims do not pay zakat to

\footnotetext{
${ }^{60}$ Fahrur Ulum, "Brotherhood Dalam Dimensi Sistem Ekonomi Islam," ISLAMICA: Jurnal Studi Keislaman 11, no. 2 (March 22, 2017): 499-521.

${ }^{61} \mathrm{Abu}$ 'Abdullah al-Hakim, Al-Mustadrak Ala Ash-Shahihain, vol. 4 (Beirut: Dar al-Fikr, 2002), 167.

62Ibn Qayyim, I'lâm al-Muwaqqi'în 'an Rabb al-'Âlamîn, vol. 3 (Riyad: Dâr Ibn alJawzî, 2002), 14.

${ }^{63}$ Muhammad Abdul Mannan, Frontiers of Islamic Economics (Delhi: Idârat alAdabîyah, 1984), 42.
}

70| Copyright (C 2021, IQTISHODUNA: Jurnal Ekonomi Islam http://ejournal.iaisyarifuddin.ac.id/index.php/iqtishoduna 
eradicate economic and social injustice. 64 According to Siddiqi, Islamic economics must fulfill the need to achieve Allah's pleasure and achieve falah in the world and the hereafter. In this sense, morality and spirituality should govern and determine economic activities. 65 Siddiqi believes that brotherhood in the Islamic Economy, when applied, can increase cooperation and sustainable virtues. Therefore, Islam places a strong emphasis on "helping behavior." This principle teaches that a person must, at the same time, strive for himself and care for the welfare of others to increase cooperation, kindness, and virtue. 66

The brotherhood nuance within the framework of an Islamic economic system includes a) relatively limited rights to individuals, communities, and the state; b) a positive and active role of the state; c) implementation of zakat and elimination of usury; and $\mathrm{d}$ ) guarantees of necessities for all. ${ }^{67}$

64 Muhammad Abdul Mannan, Islamic Economics, Theory, and Practice (Delhi: Idârat al-Adabîyah, 1980), 67; Kholis and Mugiyati, "Distribution of Productive Zakat for Reducing Urban Poverty in Indonesia," 3.

${ }^{65}$ Muhammad Nejatullah Siddiqi, Economics: An Islamic Approach (Islamabad: Institute of Policy Studies: Islamic Foundation, 2001), 109.

${ }^{66}$ Muhammad Nejatullah Siddiqi, Muslim Economic Thinking: A Survey of Contemporary Literature, Islamic economic series 1 (Jeddah : Leicester, U.K: International Centre for Research in Islamic Economics, King Abdul Aziz University; Islamic Foundation, 1981), 108.

${ }^{67}$ Muhammad Nejatullah Siddiqi, Teaching Economics in Islamic Perspective
The brotherhood has the core of mutualism, fellow human beings, and altruism, which is an attitude of being concerned with others. In the business context, a business actor should not merely pursue short-term profit but long-term oriented benefits for its sustainability and accountability in the hereafter.

The Prophet Muhammad developed the City of Medina through structured and systematic stages, making the city run well and sustainable. The first step was replacing thought patterns and activities based on ethnicity, clan, and descendant to the ashabiah in which religion is the solidarity force in the community. The next stage was ukhuwah Islamiyah, by bringing all circles together in the universal Islamic religion banner. In the final stage, with the guidance and legitimacy of Allah, the Prophet became a Mercy to the universe by implementing the Islam rahmatan lil 'alamin. Rasulullah was the leader of the Muslims in Medina from all ethnicities, clans, tribes, descendants, but for the entire universe. This strategy gave birth to brotherhood, equality, justice, and tolerance and significantly improved the economy, prosperity, wealth, and sustainability in Medina and its surroundings.

\section{CONCLUSION}

The historical reading suggests that the Islamic Brotherhood (ukhuwah Islamiyah) concept laid a

(Jeddah, Saudi Arabia: Scientific Pub. Centre, King Abdulaziz University, 1996), 4. 
critical foundation for building the Islamic community, including its economy. The Prophet Muhammad practiced this in his effort to develop Medina society in a complete form. The Islamic brotherhood concept entails a mutual bond among humans with the principle of altruism, regardless of ethnicity, religion, politics, and other backgrounds. The concept effectively eradicated the widespread tribal fanatism in Medina, hindering societal development. Ashabiah (social solidarity), the socio-cultural ties that emphasize group awareness, cohesion, and unity strengthen brotherhood solidarity. These two concepts altogether form a social capital strategy for economic development and the Islamic economic system. The Islamic Economy should aim to realize justice and virtue for all, develop pro-poor policies, and defend public interests both in consumption and production. The rahmatan lil 'alamin apostolate can mean the culmination strategy of economic development in society. This strategy gives birth to brotherhood, equality, justice, tolerance, prosperity, wealth, and sustainability.

This paper has delineated three essential concepts in economic development implemented in Islamic society, thus offering expanded insights into how the economy should be managed and developed to achieve economic justice. This article, however, solely used a narrative approach to understanding the theme, hindering it from providing a robust conclusion about the applicability of the concepts into current society. Therefore, further research needs to examine the relationships of the brotherhood and social solidarity model of economic development with the economic achievement of society. Furthermore, the rahmatan lil 'alamin economic measurements needs to be developed to examine its impacts on economic endeavors.

\section{REFERENCES}

Abdo, A. Sulaiman, and John Bagot Glubb. "Medina." Encyclopedia Britannica. Accessed March 19, 2021. https://www.britannica.co $\mathrm{m} /$ place/Medina-SaudiArabia.

Abdurrahman, Dudung, S. Maryam, A. Sodiqin, Herawati, I. Muhsin, and Irfan, Firdaus. 2004. Sejarah Peradaban Islam Dari Masa Klasik Hingga Modern. Yogyakarta: LESFI

Abi Fida' Ismail Ibnu Umar Ibnu Katsir, Imad. 1997. AlBida>yah wa al-Niha>yah, Jilid IV, (Hijr: Markaz al-Buhuts wa al-Dirasat al-Arabiyyah wa alIslamiyyah

Affandi, Hakimul Ikhwan. 2004. Akar Konflik Sepanjang Zaman: Elaborasi Pemikiran Ibn Khaldun. Cet. 1. Yogyakarta: Pustaka Pelajar. 
Moh. Syarifudin, etc: Towards Rahmatan lil 'Alamin Economy (Analysis of Ukhuwah Islamiyah and Ashabiah for Economic Development in Medina)

Ahmad, S. Moussalli, Gordon D Newby, and Ahmad Moussalli. "Muhammad." In The Oxford Encyclopedia of the Islamic World. Oxford Islamic Studies Online, n.d. Accessed March 16, 2021. http:/ / www.oxfordislamicst udies.com/opr/t236/e0550.

Ahmed, Akbar S. 2004. Islam sebagai tertuduh: kambing hitam di tengah kekerasan global. Bandung: Arasy Mizan.

Al-Qasimi, Muhammad Jamaluddin. 2003. Tafsir al-Qasimi: Mahasin at-Ta'wil. Vol. 8. Dar al-Ihya al-Kutub.

Al-Usairy, Ahmad. 2013. Sejarah Islam: Sejak Zaman Nabi Adam Hingga Abad XX. Jakarta: Akbar Media Eka Sarana.

Amin, Khairul. "Badawah \& Hadarah: Konsep Sosiologi Ibn Khaldun." Jurnal Sosiologi Agama 12, no. 1 (December 6, 2018): 85-98.

Armstrong, Michael. 1999. A Handbook of Human Resource Management Practice. 7th ed. London: Kogan Page.

Baali, Fuad, 'Ali Wardi, Mansuruddin, and Ahmadie Thoha. 1989. Ibn Khaldun dan pola pemikiran Islam. Jakarta: Pustaka Firdaus.
Baqi, Muhammad Fuad Abdul. 1992. Al-Mu'jam al-Muhfahras li AlFadl al-Quran. Mesir: Daarul Fikr.

Beik, Irfan Syauqi, and Laily Dwi Arsyianti. "Analisa Ekonomi Pertanian Ibn Khaldun." Iqtishodia: Jurnal Ekonomi Islam Republika (September 2010): 5 .

Bellah, Robert N. 1991. Beyond Belief: Essays on Religion in a PostTraditional World. Berkeley: University of California Press.

Farihah, Irzum. "Agama Menurut Ibn Khaldun." Jurnal Fikrah 2, no. 1 (2014): 187-205.

Fukuyama, Francis. 1996. Trust: The Social Virtues and The Creation of Prosperity. New York: Free Press

al-Hakim, Abu 'Abdullah. 2002. AlMustadrak Ala Ash-Shahihain. Vol. 4. Beirut: Dar al-Fikr.

Hart, Michael H. 2015. The 100: A Ranking of The Most Influential Persons In History. 1st edition. Hudson, N.J.: Kensington.

Ibn Khaldun, Abdurrahman Muhammad. 1981. Tārikh al'Allāmah Ibn Khaldūn : kitāb al'abr wa-dīwān al-mubtadā wa- 
al-khabar fi ayyām al-'Arab waal-'ajam wa-Barbar wa-man 'ạsarahum min dhawì al-sulțān al-akbar. Vol. 2. Beirut: Dar al Fikr.

- - . 2015. The Muqaddimah: An Introduction to History. Abridged Edition. Princeton, NJ: Princeton University Press.

Ibn Qayyim. 2002. I'lâm alMuwaqqi'in 'an Rabb al'Âlamîn. Vol. 3. Riyad: Dâr Ibn al-Jawzî

Ismail, Faisal, and Jabir Ahmad alHajjawi. 2017. Sejarah dan Kebudayaan Islam Periode Klasik (Abad VII-XIII M). Yogyakarta: Ircisod.

Kahf, Monzer. 1987. “Islamic Economics: Notes on Definition and Methodology." In International Workshop on the Methodology of Islamic Economics, 76-82. Nigeria: Bayero University Kano.

- - -1978. The Islamic Economy: Analytical Study of the Functioning of the Islamic Economic System. Canada: Plainfield

Khan, Muhammad Zafrulla. 2012. Muhammad, Seal of The
Prophets. Majlis Khuddamul Ahmadiyya UK.

Kholis, Nur, and Mugiyati. "Distribution of Productive Zakat for Reducing Urban Poverty in Indonesia." International Journal of Innovation, Creativity and Change 15, no. 3 (2021): 1-12.

Mannan, Muhammad Abdul. 1984. Frontiers of Islamic Economics. Delhi: Idârat al-Adabîyah.

- - . 1980. Islamic Economics, Theory, and Practice. Delhi: Idârat al-Adabîyah.

Nasution, Ali Anas. "Persaudaraan dalam Perspektif al-Qur'an." HIKMAH: Jurnal Ilmu Dakwah dan Komunikasi Islam 7, no. 2 (July 2013): 141-150.

$$
\begin{aligned}
& \text { Perspektif "Persaudaraan dalam } \\
& \text { HIKMAH: Jurnal Ilmu } \\
& \text { Dakwah dan Komunikasi Islam } \\
& \text { 7, no. } 2 \text { (July 2013): 141-150. }
\end{aligned}
$$

Otta, Yusno Abdullah. "Madinah Dan Pluralisme Sosial (Studi Atas Kepemimpinan Rasulullah)." Jurnal AlSyir'ah 8, no. 2 (2010): 479497.

Pribadi, Mohammad. 2015. Pemikiran Sosiologi Islam Ibn Khaldun. Yogyakarta: SUKA-Press. 
Moh. Syarifudin, etc: Towards Rahmatan lil 'Alamin Economy (Analysis of Ukhuwah Islamiyah and Ashabiah for Economic Development in Medina)

Pulungan, J. Suyuthi. 1994. Prinsip-

Prinsip Pemerintahan Dalam Piagam Madinah Ditinjau Dari Pandangan Al-Qur'an.

Jakarta: RajaGrafindo

Persada.

Quran.com. Surah Al-Anbya - 21:107, 2021. Accessed March 16, 2021.

https://quran.com/21/107.

"Surah Al-Hujurat - 49:10." Accessed March 16, 2021. https://quran.com/49/10?tr anslations $=20$.

QuranTranslate.com. "Surah AlHashr Ayah 9 - English Translation Quran

Translate."

QuranTranslate.Com.

Accessed March 16, 2021.

https://www.al-

quran.cc/59/9.

al-Qurtubi, Abu 'Abdullah. 2013. Tafsir Al-Qurtubi: Al-Jami' LiAhkam al-Qur'an. Vol. 8. Beirut: Risalah Publishing.

Rabie', Muhammad Mahmud. 1967. The Political Theory of Ibnu Khaldun. Leiden: E. J. Brill.

Rāzī, Muhammad ibn Abī Bakr, and 'Abd al-Fatt āh Barkāwī. 1993. Mukhtār al-Șihāḥ. Kairo:

Dār al-Manār.
al-Sabuni, Muhammad Ali. 1996. Safwat Al-Tafasir. Vol. 3. Beirut: Dar al Fikr.

al-Sadr, Muhammad Baqr. 1981. Iqtishaduna. Tehran: World Organization for Islamic Services.

Shihab, M. Quraish Shihab. 2005. Tafsir Al-Misbah Jilid 2. Jakarta: Lentera Hati. Jilid 7. Jakarta: Lentera Hati

Siddiqi, Muhammad Nejatullah. 2001. Economics: An Islamic Approach. Islamabad: Institute of Policy Studies: Islamic Foundation.

1981. Muslim Economic Thinking: A Survey of Contemporary Literature. Islamic economic series 1. Jeddah: Leicester, U.K: International Centre for Research in Islamic Economics, King Abdul Aziz University ; Islamic Foundation. 1996.Teaching Economics in Islamic Perspective. Jeddah, Saudi Arabia: Scientific Pub. Centre, King Abdulaziz University.

Sulasman, and Dadan Rusmana. 2013. Filsafat Sosial Budaya di 
Dunia Islam. Bandung: Yatim, Badri. 2016. Sejarah Peradaban Pustaka Setia. Islam. Jakarta: Rajawali Press.

Supriyadi, Dedi. 2016. Sejarah Zainuddin, A. Rahman. 1992. Peradaban Islam. Bandung: Pustaka Setia.

Kekuasaan dan Negara: Pemikiran Politik Ibnu

Syarif, Ahmad Ibrahim. 1972. Daulat Al-Rasul Fî al-Maî̀nah. Khaldun. Jakarta: Gramedia Pustaka Utama.

Kuwait: Dar al-Bayan.

Ulum, Fahrur. "Brotherhood Dalam Dimensi Sistem Ekonomi Islam." ISLAMICA: Jurnal Studi Keislaman 11, no. 2 (March 22, 2017): 499-521.

Watt, William Montgomery. 2014. Islamic Political Thought. Edinburgh: Edinburgh University Press.

Worsley, Peter. 1973. The Distribution of Power in Industrial Society. Zarkasyi, Hamid Fahmy. 2010. Peradaban Islam: Makna Dan Strategi Pembangunannya. Ponorogo: CIOS.

Zarqa', Anas. 1989. “Islamic Economics: An Approach to Human Welfare." In Readings in the Concept and Methodology of Islamic Economics, edited by Aidit Ghazali and Syed Omar, 43. Petaling Jaya: Pelanduk Publications.

London: Heinemann Educational Books.

Yakub, Muhammad. "Islam Dan Solidaritas Sosial: Perkembangan Masyarakat Islam Periode Madinah." Jurnal Pemberdayaan Masyarakat 7, no. 1 (August 24, 2019): 31-61. 